\title{
Bioavailable heavy metals in estuarine waters as assessed by metal/shell-weight indices in sentinel mussels Mytilus galloprovincialis
}

\author{
Manu Soto*, Mikel Kortabitarte, Ionan Marigómez \\ Zitologi eta Histologi Laborategia, Biologia Zelularra eta Zientzia Morfologikoen Saila, Zientzi Fakultatea, \\ Euskal HerrikoUnibertsitatea, 644 P.K., E-48080 Bilbo, Spain
}

\begin{abstract}
Seasonal variations in metal concentrations in soft tissues of marine mussels can be due, to a great extent, to seasonal changes in flesh weight. Consequently, this event results in an unpredictable overestimation of metal bioavailability when the metal concentration in soft tissues is considered as an index of such metal bioavailability. The Abra estuary (Bizkaia, Bay of Biscay, Spain) was used as a natural experimental basin with well-known differences in the levels of metallic pollutants. The level of metal bioavailability was determined at various sites at different times of the year. For this purpose the conventional approach of recording metal concentrations in soft tissues and the approach based on the calculation of metal/shell-weight indices, first proposed by Fischer (1983), were applied. We concluded that seasonal changes in organism condition (Flesh Condition Index) cause unpredictable oscillations in the metal concentration in soft tissues. For this reason the direct use of metal concentration values is not recommended to assess metal bioavailability. The metal/shell-weight indices, however, were not affected by seasonal changes in the flesh weight of sentinel mussels and thus may provide a more realistic indication of metal bioavailability. In the present study, different metal bioavailabilities, assessed by metal/shell-weight indices, were found at different sampling sites, according to the influence of industrial activities. Seasonal trends in metal/shell-weight indices (attributed to different metal inputs at different times) were also recorded. In conclusion, metal/shell-weight indices, characterized by a high sensitivity and a low noise-to-signal ratio, are a simple and reliable tool for assessing metal bioavailability in 'Mussel Watch' monitoring programmes.
\end{abstract}

KEY WORDS: Metals · Bioavailability · 'Mussel Watch' Sentinels · Molluscs · Growth · Condition · Seasonality

\section{INTRODUCTION}

The presence of toxic trace metals in the environment can be measured by direct chemical analysis of water and sediments, but this approach gives little information about the bioavailable fraction, which is the one that may provoke adverse effects on living organisms (Widdows \& Donkin 1989, Rainbow 1993). Chemical analysis of living organisms will reflect by definition, however, the bioavailability of environmental toxicants (Rainbow 1993).

The body content of a trace metal in a given organism results from the net balance between the processes of

•E-mail: gbpmaali@lg.ehu.es metal uptake and metal loss. The body concentration of a metal in a given organism, however, may be affected by a great number of factors leading to changes in flesh weight (Boyden 1974, Thomson 1982, Luoma et al. 1985, Amiard et al. 1986, Marigómez \& Ireland 1990, Cajaraville et al. 1992) and by changes in relative tissue composition associated to the reproductive cycle (Lobel \& Wright 1982a, Kraak et al. 1991, Strömgren \& Nielsen 1991, Marigómez et al. 1992a, Regoli \& Orlando 1993).

Phillips (1980) summarized the 3 factors causing seasonal changes in flesh weight and tissue composition of indicator organisms: (1) variation in the source of pollutant discharge, (2) physiological events related to seasonal cycles, and (3) changes in ambient water factors. Seasonal variations in metal concentrations in 


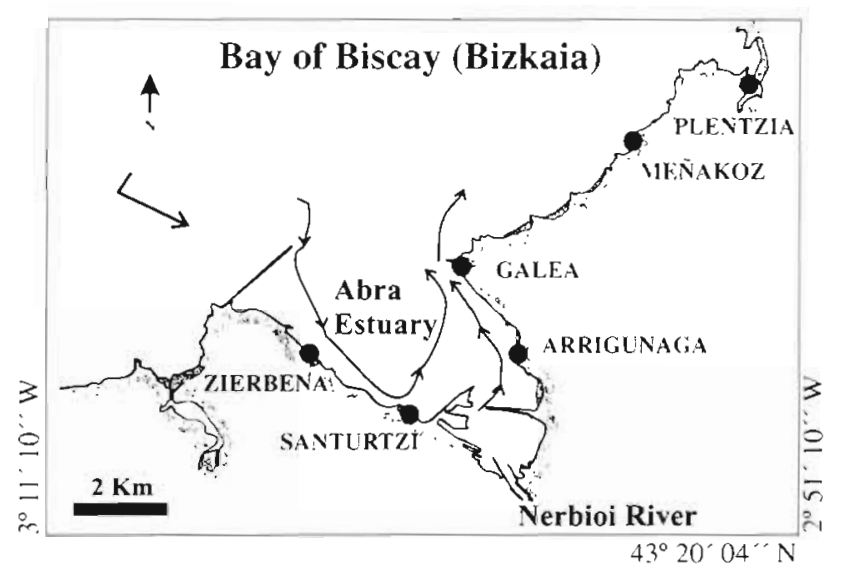

Fig. 1. Location of the sampling sites within and outside the Abra estuary in the vicinity of Bilbao. Curved arrows show the main water currents within the estuary. Arrowed angle illustrates the main wind component in the study area

soft tissues of sentinel molluscs have also been reported, with maximum peak levels in winter and minimum peaks in summer (Amiard et al. 1986, Ikuta 1988, Savari et al. 1991, Bordin et al. 1992, Regoli \& Orlando 1993). These fluctuations are not necessarily related to seasonal changes in metal bioavailability but may be related to seasonal changes in the flesh weight or in the relative tissue composition of sentinel organisms (Marigómez \& Ireland 1990, Cajaraville et al. 1992, Marigómez et al. 1992a, Regoli \& Orlando 1993).

Different approaches have been made in order to solve this problem. Fischer (1984) proposed the use of a metal index referring metal content to dry shell weight. Bordin et al. (1992) proposed the use of metal content instead of metal concentration. Additionally, Marigómez \& Ireland (1990) applied Fischer's approach in laboratory studies to estimate metal bioavailability in winkles, since metal exposure and laboratory handling themselves cause flesh weight loss from non-accumulating tissues, such as gonad and reserve storage tissues. Regoli \& Orlando (1993) used a similar index to conclude that a pronounced seasonality is observed in. lead $(\mathrm{Pb})$ concentration in the digestive gland of mussels whereas the total $\mathrm{Pb}$ content appears less variable.

Mussels have been used as sentinel organisms to assess metal bioavailability as metal content in soft tissues by shell weight unit ( $\mu \mathrm{g}$ metal in soft tissues $\mathrm{g}^{-1}$ shell weight) in the Abra estuary in the vicinity of Bilbao, Spain. The main purpose of this investigation was to validate in the field the usefulness and reliability of the metal/shell-weight index (Fischer 1983, 1984, 1986, Marigómez \& Ireland 1990, Marigómez et al. 1990 to indicate metal bioavailability from the water column.

\section{MATERIALS AND METHODS}

Experimental design. We used the Abra estuary, Spain, as a natural experimental basin with well-known differences in the levels of metallic pollutants (Azkona et al. 1984, Swindlehurst \& Johnston 1991). The Abra estuary is located in Bizkaia (Bay of Biscay, from $43^{\circ} 19^{\prime}$ to $43^{\circ}$ $23^{\prime} \mathrm{N}$, from $3^{\circ} 0^{\prime} 5^{\prime \prime}$ to $3^{\circ} 0^{\prime} \mathrm{W}$ ) and limited to the $\mathrm{NE}$ by the Galea cliffs and to the NW by the Serantes cape. Sampling sites are presented in Fig. 1.

The western sampling sites, Zierbena and Santurtzi, were expected to present intermediate levels of metallic pollution in water (Azkona et al. 1984, Swindlehurst \& Johnston 1991). The eastern sampling sites within the estuary, Galea and Arrigunaga, were expected to be heavily polluted. The coastal sites were Meñakoz and Plentzia. Meñakoz would receive little pollution from the Abra estuary but an important influence of wave turbulence. Plentzia $\left(43^{\circ} 26^{\prime} \mathrm{N}, 2^{\circ} 55^{\prime} \mathrm{W}\right)$ is a small unpolluted estuary.

Mussels Mytilus galloprovincialis Lmk. were collected monthly for 14 mo from September 1991 to October 1992 (10 September, 11 October, 6 November and 21 December 1991; 21 January, 19 February, 18 March, 4 May, 2 June, 1 July, 1 August, 31 August, 28 September and 27 October 1992). Based on previous studies (Marigómez et al. 1992b), mussels of both sexes, collected from the minimum low tide level and measuring 3.5 to $4.5 \mathrm{~cm}$ in maximum shell length, were used as sentinel specimens.

Sample processing and analysis. The mussels $(50$ site ${ }^{-1}$ and $\mathrm{mo}^{-1}$ ) were immediately transferred to the laboratory in plastic bottles within portable iceboxes. Then, mussels were placed in plastic tanks in a thermostatized $\left(13\right.$ to $\left.15^{\circ} \mathrm{C}\right)$ continuous water-flow system with active charcoal and glass-wool filtered natural seawater for $48 \mathrm{~h}$ without food in order to depurate prior to metal analysis.

After dissection, soft tissues (after removing the byssus) were rinsed in distilled water and dried at $120^{\circ} \mathrm{C}$ for 48 h until constant weight was reached. Pools of 5 mussels (giving 10 replica per sample) were digested in concentrated nitric acid, diluted with $0.1 \mathrm{M}$ nitric acid and analyzed by atomic absorption spectrophotometry (Perkin Elmer 2280 spectrophotometer) with simultaneous background correction and a sensitivity of $0.3 \mathrm{mg} \mathrm{l}^{-1}$ Merck standard solutions were diluted in $0.1 \mathrm{M}$ nitric acid for calibration. Seven metals were analyzed, cadmium (Cd), chromium (Cr), lead $(\mathrm{Pb})$, nickel $(\mathrm{Ni})$, copper $(\mathrm{Cu})$, zinc $(\mathrm{Zn})$ and iron (Fe).

The length ( $\mathrm{L}$, maximum measure along the anterior-posterior axis), height $(\mathrm{H}$, maximum dorsoventral axis), and width (W, maximum lateral axis) of each mussel shell were measured to the nearest millimetre with Vernier callipers. The shell size factor (SSF) was 
calculated as $\mathrm{L} \times \mathrm{H} \times \mathrm{W}$ in $\mathrm{mm}^{3}$. The ratios of shell height:shell length (H:L), shell width:shell height $(\mathrm{W}: \mathrm{H})$, shell width: shell length (W:L), flesh weight: shell length $(\mathrm{F}: \mathrm{L})$, flesh weight: shell height $(\mathrm{F}: \mathrm{H})$ and flesh weight: shell width $(F: W)$ were also calculated. The shells were also dried for $48 \mathrm{~h}$ until constant weight was reached. Dry flesh weight (DFW, mg) and dry upper and lower valve weights (mg) were recorded. Dry shell weight (DSW, g) was calculated from the sum of both valve weights. Flesh Condition Index (FCI) was calculated according to Lobel \& Wright (1982a) as DFW (mg)/DSW (g). Shell valve inequality index (SVI) was calculated according to Lobel \& Wright $(1982 \mathrm{~b})$ as heaviest valve dry weight $(\mathrm{mg}) \times$ 100/lightest valve dry weight (mg).

Calculation of bioavailability indices. Metal bioavailability was first calculated as metal concentrations in soft tissues ( $\mathrm{ng}$ metal $\mathrm{g}^{-1}$ dry flesh weight). Additionally, the metal/shell-weight index ( $\mu \mathrm{g}$ metal $\mathrm{g}^{-1}$ dry shell weight, or metal content per unit shell weight) was calculated according to Fischer (1984):

Metal/shell-weight index $=\frac{\left[\begin{array}{c}\text { Metal conc. in soft body }\left(\mu \mathrm{g} \mathrm{g}^{-1}\right) \\ \times \text { Dry wt of soft tissues }(\mathrm{g})\end{array}\right]}{\text { Dry shell weight }(\mathrm{g})}$

Data analysis. The geographical and seasonal variability in the biometric parameters, metal concentration in soft tissues and metal/shell-weight indices recorded was checked according to 2-way ANOVAs ( $p<0.05$ ) with site (S), month (M) and $\mathrm{S} \times \mathrm{M}$ interaction as variables.

Afterwards, sites with similar metal bioavailability (as assessed by metal/shell-weight indices) for each sampling month were clustered according to Duncan's tests $(p<0.05)$ based on 1-way ANOVAs which assessed the variability between sites for each month and between months for each site. All the analysis were made using the statistical package SPSS/PC + (SPSS, Inc., Microsoft Co.).

\section{RESULTS}

The biometric characterization of sentinel mussels is summarized in Table 1 . Since 3.5 to $4.5 \mathrm{~cm}$ length specimens were always collected, no significant difference ( $p<0.05,2$-way ANOVA) between sites and sampling months was found with the exception of $F: L, F: H$, $\mathrm{F}: \mathrm{W}$ and FCI. The variability recorded in these 4 parameters is illustrated in Fig. 2 where FCI is shown as an example. FCI decreased from September 1991 to May 1992 at all the sites. Afterwards, FCI increased in Plentzia and, to a lesser extent, in Meñakoz until September 1992. Such an increase was not recorded in Arrigunaga where, conversely, FCl values were kept over the values recorded in Plentzia during winter time. The lowest FCI values were usually recorded in mussels from Menakoz. Similar patterns were found for F:H, F:L and F:W (authors' unpubl. data).

Metal concentrations recorded in mussels are shown in Table 2 for comparison with other published data which indicate that the Abra estuary cannot be considered a highly metal-polluted area. Additionally, seasonal fluctuations for metal concentrations in Arrigunaga and Plentzia are shown in Fig. 3. For clarity, only 2 of the 7 measured metals, cadmium and chromium, are represented. According to the values of metal concentration in soft tissues, metal bioavailability appeared to be higher in winter than in summer. Metal/ shell-weight indices are also represented in Fig. 3. No

Table 1. Mytilus galloprovincialis. Average biometric parameters (mean $\pm \mathrm{SD}$ ) recorded in mussels from the Abra estuary between September 1991 and October 1992. Significant differences between sampling months (Duncan's test. $p<0.05$ ) as illustrated in Fig. 2

\begin{tabular}{|lc|}
\hline Parameters & Mean $\pm \mathrm{SD}$ \\
\hline Width $(\mathrm{mm})$ & $23.1 \pm 0.8$ \\
Length $(\mathrm{mm})$ & $40.5 \pm 0.4$ \\
Height $(\mathrm{mm})$ & $18.5 \pm 0.9$ \\
Shell Size Factor $\left(\mathrm{mm}^{3}\right)$ & $17360 \pm 1064$ \\
Height:Length $(\mathrm{mm} / \mathrm{mm})$ & $0.458 \pm 0.019$ \\
Width: Height $(\mathrm{mm} / \mathrm{mm})$ & $1.305 \pm 1.305$ \\
Width:Length $(\mathrm{mm} / \mathrm{mm})$ & $0.574 \pm 0.018$ \\
Shell Valve Inequality Index $(\mathrm{mg} / \mathrm{mg})$ & $0.967 \pm 0.005$ \\
Flesh weight:Length & $\cdot$ \\
Flesh weight:Height & $\cdot$ \\
Flesh weight:Width & $\cdot$ \\
Flesh Condition Index & $\cdot$ \\
\hline
\end{tabular}

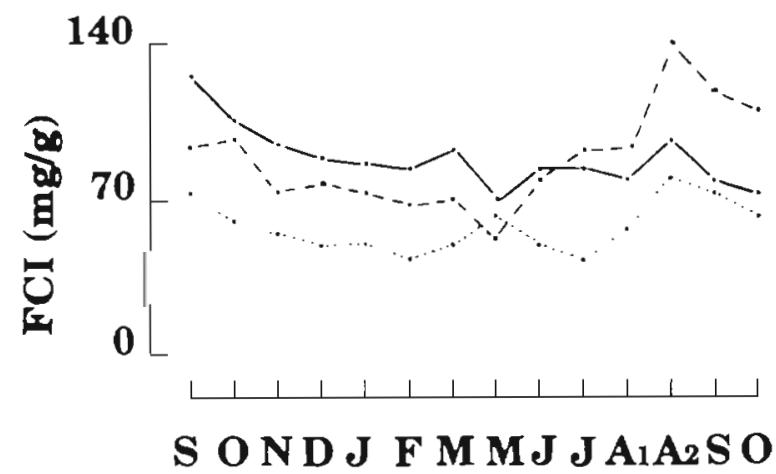

Fig. 2. Mytilus galloprovincialis. Flesh Condition Index (mg dry flesh weight/g dry shell weight) recorded at 3 selected sites, Arrigunaga ( - - - ), Plentzia (-.--.-) and Meñakoz $($ (.........). S: September 1991; O: October 1991; N: November 1991; D: December 1991; J: January 1992; F: February 1992; M: March 1992; M: May 1992; J: June 1992; July 1992; A1 Early August 1992; A2: Late August 1992; S: September 1992; O: October 1992 
Table 2. Mytilus galloprovincialis. Metal concentration ( $\left.\mathrm{gg} \mathrm{g}^{-1}\right)$ found in the soft tissues of sentinel mussels (mean $\pm \mathrm{SD}$ ) between September 1991 and October 1992 for each site. Minimum and maximum concentration values are shown in brackets

\begin{tabular}{|ccccccc|}
\hline Metal & Santurtzi & Zierbena & Arrigunaga & Galea & Meñakoz & Plentzia \\
\hline $\mathrm{Ni}$ & $2.359 \pm 1.472$ & $2.150 \pm 1.406$ & $1.909 \pm 1.084$ & $2.494 \pm 1.492$ & $2.226 \pm 1.531$ & $1.637 \pm 1.449$ \\
& $(0.3-6.29)$ & $(0-6.6)$ & $(0.36-5.72)$ & $(0.63-8.09)$ & $(0.48-6.93)$ & $(0.23-7.72)$ \\
$\mathrm{Pb}$ & $2.132 \pm 1.283$ & $2.127 \pm 1.298$ & $2.028 \pm 0.912$ & $2.391 \pm 1.442$ & $2.314 \pm 1.822$ & $1.806 \pm 1.246$ \\
& $(0-5.32)$ & $(0-6.15)$ & $(0.18-4.34)$ & $(0-11.79)$ & $(0-19.27)$ & $(0-7.93)$ \\
$\mathrm{Cd}$ & $1.318 \pm 0.909$ & $1.219 \pm 0.809$ & $1.395 \pm 0.718$ & $2.175 \pm 1.601$ & $0.990 \pm 0.532$ & $0.671 \pm 0.482$ \\
& $(0.27-5.29)$ & $(0.29-5.28)$ & $(0.3-3.72)$ & $(0.27-8.45)$ & $(0.12-3.23)$ & $(0.16-2.69)$ \\
$\mathrm{Cr}$ & $2.023 \pm 1.081$ & $1.970 \pm 0.859$ & $2.159 \pm 0.979$ & $2.601 \pm 0.913$ & $1.934 \pm 0.715$ & $1.223 \pm 0.688$ \\
& $(0.39-5.49)$ & $(0.35-4.84)$ & $(0.53-6.85)$ & $(0.76-5.76)$ & $(0.38-4.06)$ & $(0.25-3.58)$ \\
$\mathrm{Cu}$ & $4.781 \pm 3.073$ & $4.850 \pm 2.526$ & $4.219 \pm 2.083$ & $5.764 \pm 2.985$ & $4.610 \pm 2.963$ & $3.052 \pm 1.798$ \\
& $(0.45-12.78)$ & $(0.63-10.17)$ & $(0.86-11.64)$ & $(1.05-14.05)$ & $(0.23-26.55)$ & $(0.21-7.76)$ \\
$\mathrm{Fe}$ & $138.727 \pm 96.541$ & $659.322 \pm 517.460$ & $159.621 \pm 75.821$ & $246.138 \pm 172.846$ & $137.476 \pm 82.426$ & $110.059 \pm 55.177$ \\
& $(28.39-721.71)$ & $(69.10-3481.53)$ & $(42.29-486.99)$ & $(59.97-836.28)$ & $(23.95-555.31)$ & $(23.14-291.10)$ \\
$\mathrm{Zn}$ & $106.638 \pm 99.792$ & $111.291 \pm 91.765$ & $65.965 \pm 37.048$ & $121.852 \pm 124.238$ & $96.523 \pm 71.255$ & $76.572 \pm 105.937$ \\
& $(19.15-505.73)$ & $(16.63-467.89)$ & $(5.05-216.24)$ & $(9.76-648.96)$ & $(6.65-352.71)$ & $(4.17-531.88)$ \\
\hline
\end{tabular}
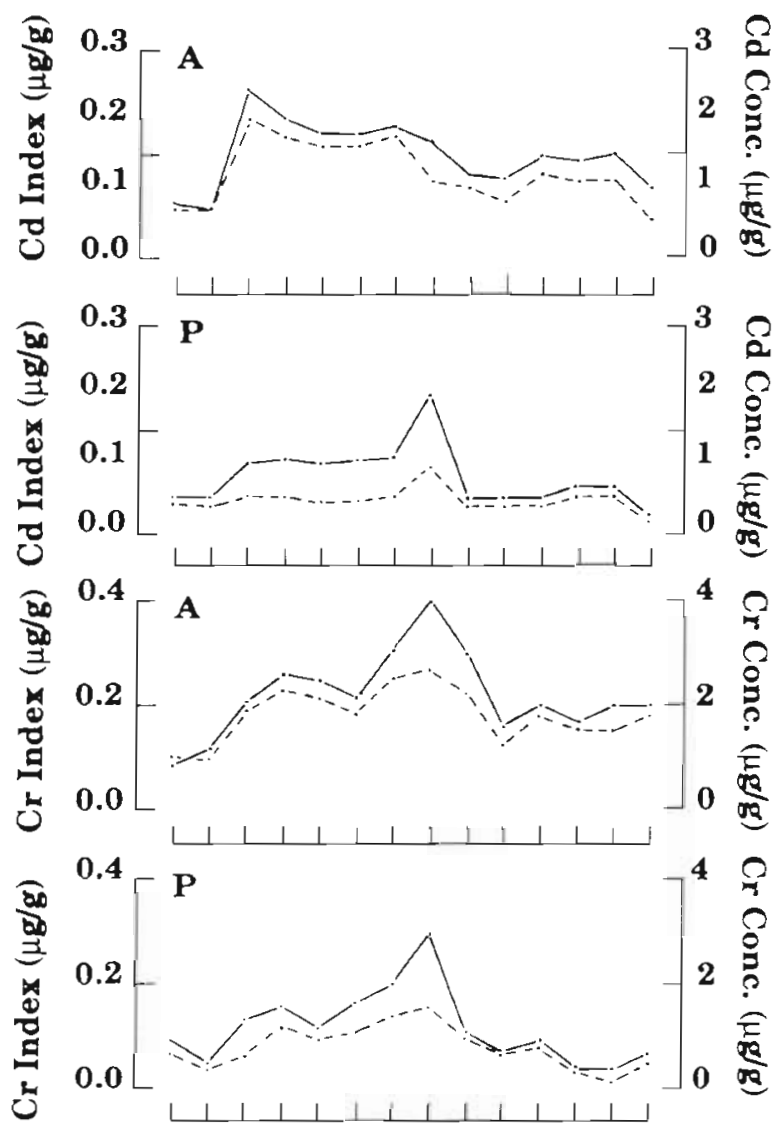

S O N D J F M M J J A $1 A_{2} S O$

Fig. 3. Mytilus galloprovincialis. Graphs comparing metal shell-weight indices ( $\cdot-\cdot--)$ ) and metal concentration values ( - - - ) for $\mathrm{Cd}$ and $\mathrm{Cr}$ throughout the sampling time at 2 selected sites (A, Arrigunaga; P, Plentzia). Abbreviations as in Fig. 2 seasonal fluctuation was recorded at Plentzia, with the exception of the $\mathrm{Cd} /$ shell-weight index which increased in May 1992. In Arrigunaga, however, an increased metal bioavailability was found in winter.

Metal/shell-weight indices were used to characterize each site and month depending on the metal bioavailability. Thus, sites were put together in clusters of similar metal bioavailability (Duncan's test, $\mathrm{p}<0.05$ ) for each sampling month (Fig. 4). The different metal bioavailability between sampling months is indicated by different encircled grey areas (Fig. 4). The information provided in Fig. 4 is complemented by tables showing the values of metal/shell-weight indices characterizing each cluster. Although Zierbena was included within a given cluster, it always presented an especially high iron bioavailability as indicated within brackets in the adjoining table (Fig. 4). For this reason it is usually marked separately within the respective cluster.

In general terms, metal/shell-weight indices also indicate that metal bioavailability was not very high in the Abra estuary between September 1991 and November 1992. As an exception, iron bioavailability was high in Zierbena. Occasionally, high iron bioavailability was found in Arrigunaga and Galea. High $\mathrm{Cr}$ and $\mathrm{Cd}$ bioavailability and moderate $\mathrm{Ni}, \mathrm{Cu}$ and $\mathrm{Pb}$ bioavailability were usually found in Arrigunaga and, to a lesser extent, Galea. Metal bioavailability was lower in Plentzia than at any other site.

The seasonal trend in metal bioavailability may be seen in Fig. 4 but it is more clearly represented in Fig. 5, where only 2 sites (Plentzia and Arrigunaga) are shown. Plentzia and Arrigunaga represent the 2 main clusters defined in Fig. 4 
From September 1991 to November 1991, Arrigunaga and Galea showed higher metal bioavailability than sites on the left side and out of the estuary (Fig. 4). From November 1991 to March 1992, a high metal bioavailability was found in the inner part of the estuary, with values over those recorded in the 2 previous months. In summer, from June 1992 to early August 1992, a general decline in metal bioavailability was observed, the highest bioavailability being restricted again to the inner part of the estuary. In late August 1992, the metal bioavailability found in Zierbena was close to that exhibited by Arrigunaga and Santurtzi. Afterwards, metal bioavailability decreased at all sampling points, mostly in Plentzia, in October 1992. $\mathrm{Ni}$ bioavailability was higher in summer than in winter. $\mathrm{Zn}$ and $\mathrm{Cd}$ bioavailability occasionally increased in Plentzia in May 1992

\section{DISCUSSION}

Many authors have found seasonal variations in the metal concentrations recorded in marine molluscs (Pentreath 1973, Bryan 1976, Phillips 1976). In general terms, the concentration of metals in soft tissues is higher in winter than in summer as reported for many marine bivalves: Mytilus edulis (Phillips 1976, Amiard et al. 1986), M. galloprovincialis (Majori et al. 1978), Perna viridis (Chu et al. 1990), Crassostrea gigas (Boyden \& Phillips 1981) and Macoma balthica (Bordin et al. 1992). In addition, Phillips (1976) concluded that high flesh weights in mussels were associated with low metal concentrations whilst metal contents did not change with individual weight. Abdullah \& Ireland (1986) also found higher metal concentrations in lowweight dog whelks collected in winter than in highweight dog whelks collected in summer. In the present study, we found a reduced flesh weight and a decreased general organism condition (FCI) in mussels from the Abra estuary during winter, when increased metal concentrations were recorded. Conversely, reduced metal concentrations, increased body weight and improved organism condition were recorded in summer. In conclusion, it seems that seasonal variations in metal concentrations in soft tissues of marine mussels can be due, to a great extent, to seasonal changes in flesh weight, in agreement with the results of previous works (Cossa et al. 1979, Lobel \& Wright 1982a, b).

Hawkins \& Bayne (1985) found that the body weight of mussels changes seasonally according to the relative rate of somatic or gonadal growth occurring at different periods of the life cycle. Talbot (1985) found prespawning body weight increases leading to highest peak values in summer and body weight decreases through winter. Morchid (1989) reported that a great amount of reserves was found in the non-mantle tissues of Mytilus galloprovincialis from October to May, whilst storage reserves increased in all tissues, including mantle, in summer Thus, in late spring and summer, trace metals may be diluted by increasing the flesh weight (Borchardt et al. 1989) during the period of more intense somatic growth. In autumn and winter, however, gonadal and storage tissues, which do not accumulate metals (Savari et al. 1991), may be resorbed and, hence, flesh weight would be reduced without major changes in the metal contents in the whole body. Consequently, seasonal differences in tissue composition may also result in an unpredictable overestimation of metal bioavailability when the conventional approach of recording metal concentration in soft tissues is applied.

Aware of this problem, Martin (1992) rejected gonads in metal bioavailability assessment because of the seasonal variability observed in the gonad mass of mussels. The problem, however, is not fully resolved in this way because seasonal changes in the rate of somatic growth were not taken into account. This difficulty can be overcome to a greater extent by simply relating the body burden of metals to the weight of the calcareous shell (Fischer 1983). The so-called metal/shell-weight index is independent of conditions such as nutritional stage, spawning, or tidal exposure (Fischer 1983) and of environmental factors such as temperature, salinity and oxygen levels (Fischer 1986). The metal/shell-weight index is also independent of changes in organism condition associated with the presence of pollutants, including metals (Marigómez \& Ireland 1990) and has been significantly correlated with the biological effects of metals quantified at the cell and organism levels (Marigómez et al. 1990).

In the present field investigation, shell dry weights did not change significantly over the year for mussels measuring 3.5 to $4.5 \mathrm{~cm}$ in shell length. At a nonpolluted site, such as Plentzia, the Cd concentration, for instance, changed seasonally but, conversely, the $\mathrm{Cd} /$ shell-weight index did not exhibit seasonal fluctuations, as could be expected by absence of local inputs. At a polluted site, such as Arrigunaga, both $\mathrm{Cd}$ concentration and $\mathrm{Cd} /$ shell-weight index changed seasonally in relation to the intensity of the industrial activity, indicating fluctuations in metal bioavailability. Consequently, the present field study supports the proposition that metal/shell-weight indices provide a method to detect differences and changes in the bioavailability of cumulative metals, as Fischer (1988) concluded from laboratory studies and Regoli \& Orlando (1993) applied to the particular case of $\mathrm{Pb}$-exposed mussels. Since the term metal/shell-weight index (Fischer 1983, 1984, $1986,1988)$ might be misinterpreted as a measure of 


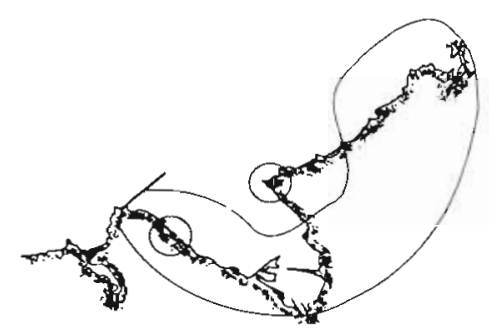

September 1991

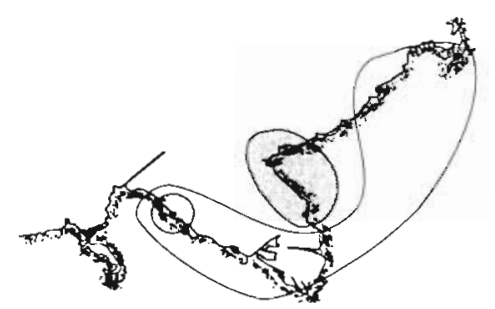

$17.0^{\circ} \mathrm{C}$

$130.0 \mathrm{~mm}$

October 1991

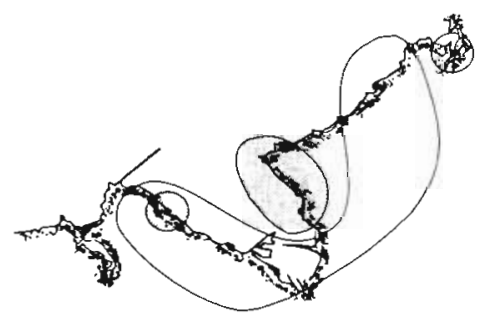

November 1991
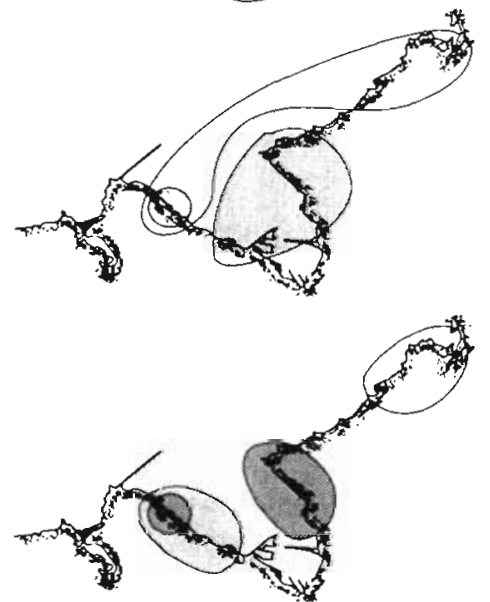

\section{December 1991}

$6.9^{\circ} \mathrm{C}$

$33.4 \mathrm{~mm}$

January 1992

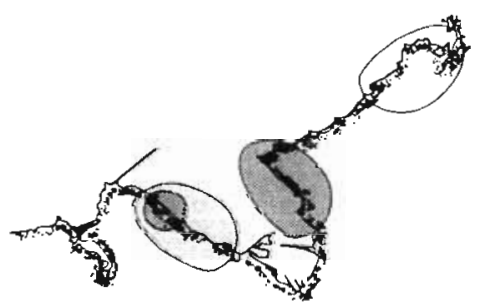

$8.0^{\circ} \mathrm{C}$ $27.5 \mathrm{~mm}$

\section{February 1992}

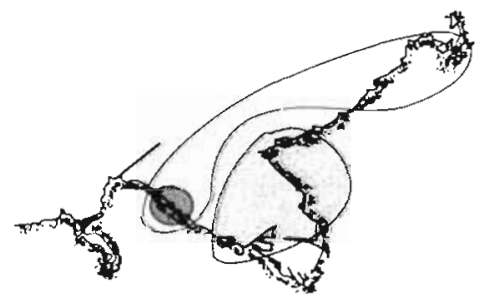

$9.6{ }^{\circ} \mathrm{C}$ $65.0 \mathrm{~mm}$

March 1992

\begin{tabular}{|l|l|l|l|}
\cline { 2 - 3 } \multicolumn{1}{c|}{} & PMSZA & $\mathrm{G}$ \\
\hline $\mathrm{Fe}$ & $7.412 \pm 2.168$ & $13.742(\mathrm{Z})$ & 10.860 \\
\hline $\mathrm{Cr}$ & $0.095 \pm 0.016$ & 0.143 \\
\hline $\mathrm{Ni}$ & $0.071 \pm 0.009$ & 0.095 \\
\hline $\mathrm{Pb}$ & $0.033 \pm 0.014$ & 0.011 \\
\hline $\mathrm{Cu}$ & $0.208 \pm 0.042$ & 0.364 \\
\hline $\mathrm{Zn}$ & $8762 \pm 1.533$ & 11.023 \\
\hline $\mathrm{Cd}$ & $0.055 \pm 0.017$ & 0.122 \\
\hline
\end{tabular}

\begin{tabular}{|c|c|c|c|}
\hline & PMSZ & & $\mathrm{AG}$ \\
\hline $\mathrm{Fe}$ & $9.523 \pm 2.471$ & $22.707(\mathrm{Z})$ & $23.117 \pm 0.609$ \\
\hline $\mathrm{Cr}$ & $0.081 \pm 0.010$ & & $0.126 \pm 0.027$ \\
\hline $\mathrm{Ni}$ & $0.070 \pm 0.011$ & & $0.114(\mathrm{~A})$ \\
\hline $\mathrm{Pb}$ & $0.155+0.033$ & & \\
\hline $\mathrm{Cu}$ & $0.231 \pm 0.018$ & $0.287(\mathrm{Z})$ & $0.336 \pm 0.01$ \\
\hline $\mathrm{Zn}$ & $3.634 \pm 2.025$ & & \\
\hline$\overline{C d}$ & $0.042 \pm 0.007$ & & $0.096 \pm 0.031$ \\
\hline
\end{tabular}

\begin{tabular}{|l|l|l|l|l|}
\cline { 2 - 5 } \multicolumn{1}{c|}{} & $\mathrm{P}$ & \multicolumn{1}{l|}{$\mathrm{MSZ}$} & $\mathrm{AG}$ \\
\hline $\mathrm{Fe}$ & 12.722 & $17.142 \pm 3.414$ & $50.334(\mathrm{Z})$ & $30.300 \pm 6.855$ \\
\hline $\mathrm{Cr}$ & 0.085 & $0.139 \pm 0.013$ & $0.192 \pm 0.001$ \\
\hline $\mathrm{Ni}$ & 0.051 & $0.114 \pm 0.048$ & $0.176 \pm 0.010$ \\
\hline $\mathrm{Pb}$ & $0.120 \pm 0.040$ & \multicolumn{3}{|l}{} \\
\hline $\mathrm{Cu}$ & 0.189 & $0.354 \pm 0.037$ & $0.585 \pm 0.080$ \\
\hline $\mathrm{Zn}$ & 3.048 & $9.699 \pm 1.701$ & $9.699 \pm 1.706$ \\
\hline $\mathrm{Cd}$ & 0.0584 & $0.123 \pm 0.041$ & $0.184 \pm 0.013$ \\
\hline
\end{tabular}

\begin{tabular}{|l|l|l|l|}
\cline { 2 - 3 } \multicolumn{1}{c|}{} & $\mathrm{PMZ}$ & \multicolumn{1}{c|}{} & $\mathrm{AGS}$ \\
\hline $\mathrm{Fe}$ & $8.933 \pm 2.391$ & $39.068(\mathrm{Z})$ & $12.536 \pm 2.729$ \\
\hline $\mathrm{Cr}$ & $0.134 \pm 0.009$ & $0.189 \pm 0.037$ \\
\hline $\mathrm{Ni}$ & $0.089 \pm 0.012$ & $0.130 \pm 0.038$ \\
\hline $\mathrm{Pb}$ & $0.114 \pm 0.013$ & $0.157 \pm 0.019$ \\
\hline $\mathrm{Cu}$ & $0.317 \pm 0.033$ & $0.438 \pm 0.127$ \\
\hline $\mathrm{Zn}$ & $9.497 \pm 4.028$ & $10.752 \pm 5.631$ \\
\hline $\mathrm{Cd}$ & $0101 \pm 0.036$ & $0.187 \pm 0.079$ \\
\hline
\end{tabular}

\begin{tabular}{|c|c|c|c|c|}
\hline & PM & $\mathrm{SZ}$ & & $\mathrm{AG}$ \\
\hline $\mathrm{Fe}$ & $7.879 \pm 0.398$ & $9.212(\mathrm{~S})$ & $69.041(\mathrm{Z})$ & $15.773 \pm 4.46$ \\
\hline $\mathrm{Cr}$ & $0.113 \pm 0.017$ & \multicolumn{2}{|c|}{$0.147 \pm 0.008$} & $0.181 \pm 0.032$ \\
\hline $\mathrm{Ni}$ & $0.138 \pm 0.022$ & \multicolumn{2}{|c|}{$0.195 \pm 0.036$} & $0.203 \pm 0.031$ \\
\hline $\mathrm{Pb}$ & \multicolumn{4}{|l|}{$0.228 \pm 0.059$} \\
\hline $\mathrm{Cu}$ & $0.405 \pm 0.124$ & \multicolumn{2}{|l|}{$0.409 \pm 0.081$} & $0.555 \pm 0.074$ \\
\hline $\mathrm{Zn}$ & \multicolumn{4}{|l|}{$4.943 \pm 0.788$} \\
\hline $\mathrm{Cd}$ & $0.056 \pm 0.001$ & $0.085 \pm 0.022$ & & $0.144 \pm 0.004$ \\
\hline
\end{tabular}

\begin{tabular}{|l|l|l|l|l|}
\cline { 2 - 5 } \multicolumn{1}{c|}{} & $\mathrm{PM}$ & $\mathrm{SZ}$ & $\mathrm{AG}$ \\
\hline $\mathrm{Fe}$ & $7.851 \pm 2.085$ & $10.225(\mathrm{~S})$ & $66.724(\mathrm{Z})$ & $15.915 \pm 3.783$ \\
\hline $\mathrm{Cr}$ & $0.115 \pm 0.008$ & $0.149 \pm 0.037$ & & $0.183 \pm 0.004$ \\
\hline $\mathrm{Ni}$ & $0.095 \pm 0.033$ & \multicolumn{3}{l}{} \\
\hline $\mathrm{Pb}$ & $0.162 \pm 0.019$ & & $0.238(\mathrm{~A})$ \\
\hline $\mathrm{Cu}$ & $0.289 \pm 0.033$ & $0.377 \pm 0.055$ & & \\
\hline $\mathrm{Zn}$ & $4494 \pm 1.252$ & & $12.435(\mathrm{Z})$ & $4.494 \pm 1.252$ \\
\hline $\mathrm{Cd}$ & $0.052 \pm 0.005$ & $0.072 \pm 0.018$ & & $0.145 \pm 0.001$ \\
\hline
\end{tabular}

\begin{tabular}{|l|l|l|l|}
\cline { 2 - 4 } \multicolumn{1}{c|}{} & \multicolumn{2}{l|}{} & \multicolumn{1}{l|}{ AGS } \\
\hline $\mathrm{Fe}$ & $9.080 \pm 2.613$ & $63.526(\mathrm{Z})$ & $16.480 \pm 7.967$ \\
\hline $\mathrm{Cr}$ & $0.135 \pm 0.008$ & $0.202 \pm 0.045$ \\
\hline $\mathrm{Ni}$ & $0.118 \pm 0.026$ & $0.188 \pm 0.054$ \\
\hline $\mathrm{Pb}$ & $0.209 \pm 0.064$ & \multicolumn{1}{|l|}{} \\
\hline $\mathrm{Cu}$ & $0.354 \pm 0.044$ & $0.494 \pm 0.068$ \\
\hline $\mathrm{Zn}$ & $4.031 \pm 1000$ & $12.213(\mathrm{~S})$ \\
\hline $\mathrm{Cd}$ & $0.060 \pm 0.004$ & $0.090(\mathrm{Z})$ & $0.120 \pm 0.037$ \\
\hline
\end{tabular}

Fig. 4. Mytilus galloprovincialis. Maps showing site clusters (Duncan's test, $\mathrm{p}<0.05$ ) obtained according to metal bioavailability, indicated by different encircled areas (from white to dark grey at increasing bioavailabiluty). Metal/shell-weight indices characterizing each cluster (mean $\pm \mathrm{SD}$ ) are given in the adjoining table. Dissimilar values in metal bioavailablity withun a cluster are shown separately for particular sites (Z: Zierbena; S: Santurtzi; A: Arrigunaga; G: Galea; M: Meñakoz; P: Plentzia). Mean temperature and rainfall values are indicated for each month 

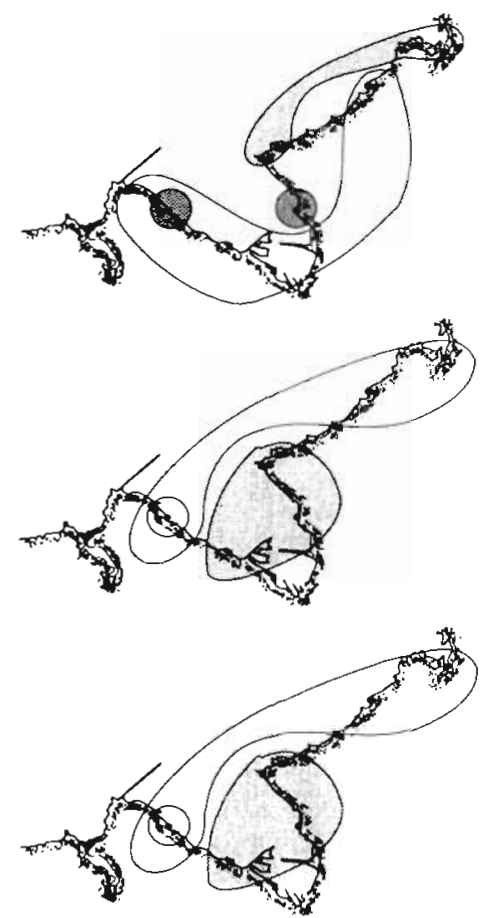

June 1992

$11.8^{\circ} \mathrm{C}$

$67.7 \mathrm{~mm}$

May 1992

$17.1^{\circ} \mathrm{C}$

$38.9 \mathrm{~mm}$

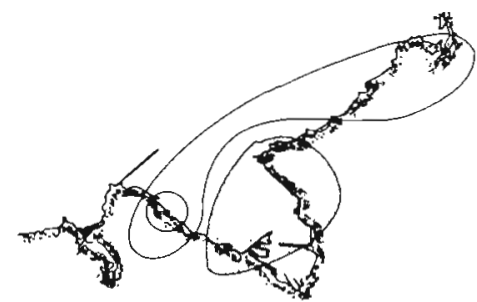

Early August 1992

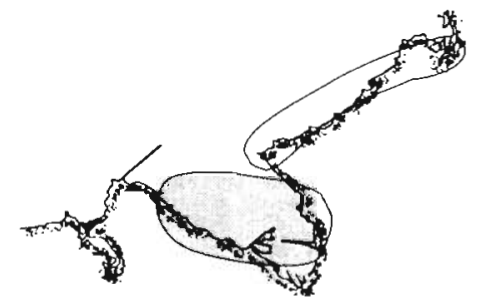

$21.0^{\circ} \mathrm{C}$

$105.9 \mathrm{~mm}$

Late August 1992

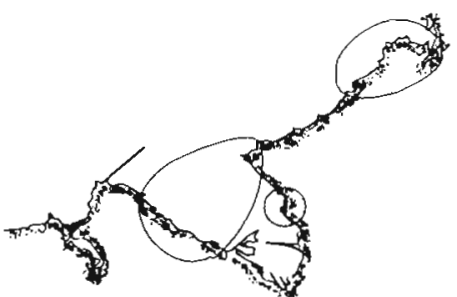

$17.8^{\circ} \mathrm{C}$

$100.2 \mathrm{~mm}$

September 1992

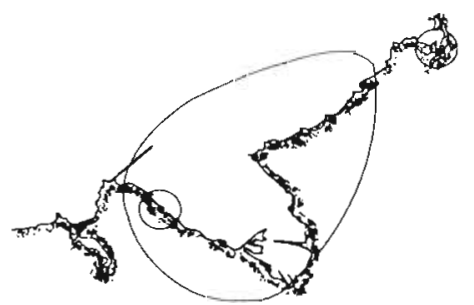

October 1992 $13.1^{\circ} \mathrm{C}$ $432.2 \mathrm{~mm}$

\begin{tabular}{|c|c|c|c|c|}
\hline & $P G$ & A & MSZ & \\
\hline $\mathrm{Fe}$ & $9483 \pm 2.868$ & & & $63.798(\mathrm{Z})$ \\
\hline $\mathrm{Cr}$ & $0.1619 \pm 0.015$ & 0.277 & $0.179 \pm 0.003$ & \\
\hline $\mathrm{Ni}$ & $0.249 \pm 0.073$ & & & \\
\hline $\mathrm{Fb}$ & $0.198 \pm 0.059$ & & & \\
\hline Civi & $0.286 \pm 0.047$ & $0.427 \pm 0.028$ & & \\
\hline $\mathrm{Zn}$ & $11973 \pm 8.687$ & & & \\
\hline $\mathrm{Cd}$ & $0.233(\mathrm{G})$ & $0.093 \pm 0.020$ & & \\
\hline
\end{tabular}

\begin{tabular}{|l|l|l|l|}
\cline { 2 - 3 } \multicolumn{1}{c|}{} & PMZ & AGS \\
\hline $\mathrm{Fe}$ & $7 \frac{250 \pm 2.101}{\mathrm{Fr}}$ & $29.027(\mathrm{Z})$ & $7.250 \pm 2.101$ \\
\hline $\mathrm{Cr}$ & $0 . \overline{105 \pm 0.019}$ & $0.228(\mathrm{~A}) 0.146 \pm 0.029(\mathrm{GS})$ \\
\hline $\mathrm{Ni}$ & $0.213 \pm 0.025$ & $0.288 \pm 0.028$ \\
\hline $\mathrm{Pb}$ & $0.120 \pm 0.034$ & \\
\hline $\mathrm{Cu}$ & $0.187 \pm 0.012$ & $0.285 \pm 0.043$ \\
\hline $\mathrm{Zn}$ & $3.662 \pm 1.198$ & \\
\hline $\mathrm{Cd}$ & $0047 \pm 0.012$ & $0.076 \pm 0.010$ \\
\hline
\end{tabular}

\begin{tabular}{|c|c|c|c|}
\hline & \multicolumn{2}{|l|}{ PMZ } & AGS \\
\hline $\mathrm{Fe}$ & $7.540 \pm 1.310$ & $27.113(\mathrm{Z})$ & $7540 \pm 1.310$ \\
\hline $\mathrm{Cr}$ & \multicolumn{2}{|l|}{$0.080 \pm 0.017$} & $0.116 \pm 0.024$ \\
\hline $\mathrm{Ni}$ & \multicolumn{2}{|l|}{$0.213 \pm 0.03$} & $0.276 \pm 0.06(\mathrm{AS}) 0.124(\mathrm{G})$ \\
\hline $\mathrm{Pb}$ & \multicolumn{2}{|l|}{$0.111 \pm 0.160$} & $0.183 \pm 0.934$ \\
\hline $\mathrm{Cu}_{1}$ & $0.197 \pm 0.060(\mathrm{PM})$ & $0.315 \pm 0.001(\mathrm{SZ})$ & $0.364 \pm 0.001(\mathrm{AG})$ \\
\hline$Z_{n}$ & \multicolumn{3}{|l|}{$3.123 \pm 0.809$} \\
\hline $\mathrm{Cd}$ & $0.035 \pm 0.005$ & & $0.053 \pm 0.010$ \\
\hline
\end{tabular}

\begin{tabular}{|l|l|l|l|}
\cline { 2 - 3 } \multicolumn{1}{c|}{} & $\mathrm{PMZ}$ & \multicolumn{1}{|c|}{$\mathrm{AGS}$} \\
\hline $\mathrm{Fe}$ & $6.380 \pm 0.220$ & $18.621(\mathrm{Z})$ & $12.994 \pm 0.210$ \\
\hline $\mathrm{Cr}$ & $0.092 \pm 0.010$ & $0.149 \pm 0.02$ \\
\hline $\mathrm{Ni}$ & $0.207 \pm 0.037(\mathrm{PM})$ & $0.096 \pm 0.020(\mathrm{SZG})$ & $0.254(\mathrm{~A})$ \\
\hline $\mathrm{Pb}$ & $0.120 \pm 0.030$ & \\
\hline $\mathrm{Cu}$ & $0.234 \pm 0.058$ & \\
\hline $\mathrm{Zn}$ & $4.643 \pm 1.494$ & \\
\hline $\mathrm{Cd}$ & $0.040 \pm 0.010$ & $0.100 \pm 0.031$ \\
\hline
\end{tabular}

\begin{tabular}{|l|l|l|}
\cline { 2 - 3 } \multicolumn{1}{c|}{} & $P M G$ & SZA \\
\hline $\mathrm{Fe}$ & $7.734 \pm 3.391$ & $18.422 \pm 9.532$ \\
\hline $\mathrm{Cr}$ & $0.069 \pm 0.015$ & $0.117 \pm 0.034$ \\
\hline $\mathrm{Ni}$ & $0.096 \pm 0.015$ & $0.134 \pm 0.044$ \\
\hline $\mathrm{Pb}$ & $0.105 \pm 0.039$ & \\
\hline $\mathrm{Cu}$ & $0.135 \pm 0.062$ & $0.339 \pm 0.062$ \\
\hline $\mathrm{Zn}$ & $4.919 \pm 3.020$ & \\
\hline $\mathrm{Cd}$ & $0.062 \pm 0.017$ & $0.087 \pm 0.027$ \\
\hline
\end{tabular}

\begin{tabular}{|l|l|l|l|}
\cline { 2 - 4 } \multicolumn{1}{c|}{} & $\mathrm{PM}$ & $\mathrm{SZG}$ & $\mathrm{A}$ \\
\hline $\mathrm{Fe}$ & $9.959 \pm 1.769$ & $23.552(\mathrm{Z})$ & $9.959 \pm 1.769$ \\
\hline $\mathrm{Cr}$ & $0.052 \pm 0.010$ & $0.085 \pm 0.016$ & 0.156 \\
\hline $\mathrm{Ni}$ & $0.063 \pm 0.009$ & 0.144 \\
\hline $\mathrm{Pb}$ & $0.140 \pm 0.185$ & & \\
\hline $\mathrm{Cu}$ & $0.129 \pm 0.040$ & $0.138 \pm 0.037$ & 0.258 \\
\hline $\mathrm{Zn}$ & $4.836 \pm 4.255$ & \\
\hline $\mathrm{Cd}$ & $0.062 \pm 0.013$ & 0.116 \\
\hline
\end{tabular}

\begin{tabular}{|c|c|c|c|}
\hline & $P$ & ZSAGM & \\
\hline $\mathrm{Fe}$ & $6.082 \pm 0.677$ & & $11.630(\mathrm{Z})$ \\
\hline $\mathrm{Cr}$ & 0.084 & $0.133 \pm 0.023$ & \\
\hline $\mathrm{Ni}$ & 0.044 & $0.081 \pm 0.028$ & \\
\hline $\mathrm{Pb}$ & $0.077 \pm 0.300$ & & \\
\hline $\mathrm{Cu}$ & 0.063 & $0.150 \pm 0.017$ & \\
\hline $\mathrm{Zn}$ & 1.584 & $4.503 \pm 0.607$ & \\
\hline $\mathrm{Cd}$ & 0.025 & $0.065 \pm 0.019$ & \\
\hline
\end{tabular}




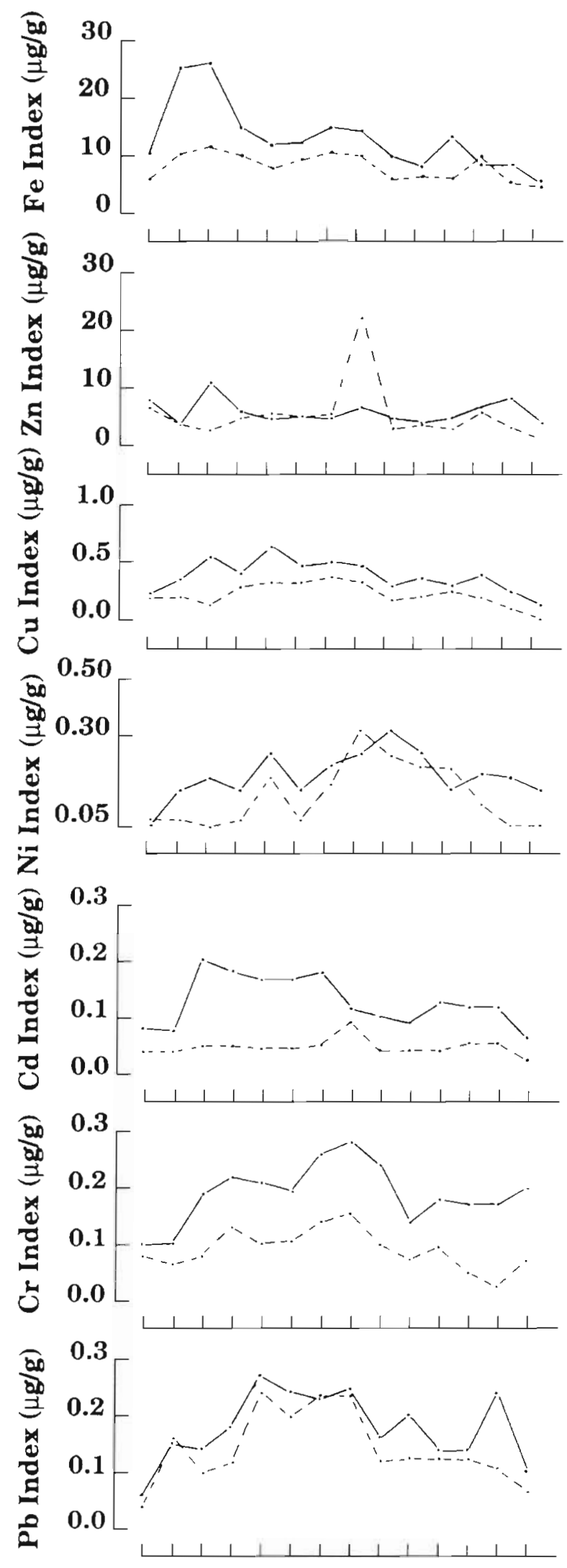

SOND J F M MJ J A $\mathrm{A}_{2} \mathrm{SO}$ shell metal content, we suggest using Fischer's bioavailability index as a routine name for the metal burden in flesh related to shell weight in sentinel mussels.

Such an index was applied in this study to investigate the metal bioavailability in the Abra estuary, which was previously reported to receive important metal inputs ( $\mathrm{Cd}, \mathrm{Cr}, \mathrm{Ni}, \mathrm{Pb}, \mathrm{Cu}, \mathrm{Zn}$ and $\mathrm{Fe}$ ) by Azkona et al. (1984), Swindlehurst \& Johnston (1991) and Ruiz de la Rosa \& Saiz-Salinas (1993). The results (Table 2) indicate that metal bioavailability in the Abra estuary, determined by the conventional use of metal concentration values, is lower than expected from previous reports (Azkona et al. 1984, Swindlehurst \& Jonhston 1991, Ruiz de la Rosa \& Saiz-Salinas 1993) and could be classified as a site moderately polluted by metals (Phillips 1976, Talbot 1985, Lobel et al. 1991). In fact, the studies of Swindlehurst \& Jonhston (1991) and Ruiz de la Rosa \& Saiz-Salinas (1993) were carried out within the commercial harbour towards the industrial area of the river, whilst our study deals with the area of the river mouth, just out of the commercial harbour.

Secondly, in agreement with our former conclusion, the metal/shell-weight indices recorded in the present work were similar to those found in unpolluted sites (Fischer 1989). Different metal bioavailabilities have been found, however, at different sites in relation to the influence of the waters outcoming from the highly industrialized Nerbioi river. Thus, metal bioavailability was generally higher on the eastern side of the estuary (Arrigunaga and Galea) than on the western side (Zierbena and Santurtzi) and the outer sampling sites (Meñakoz and Plentzia). The eastern side receives the direct influence of the industrialized Nerbioi river whereas the western side is mainly influenced by water coming from the open sea, as a result of wind and water currents (Fig. 1). Interestingly, according to the metal concentration values a high metal bioavailability was envisaged in Meñakoz where flesh weight was heavily depressed due to the continuous stress provoked by very strong wave turbulence. When metal/shell-weight indices were applied, however, Meñakoz resulted to be a nonpolluted site, as expected from the scarce influence of industrial inputs.

Finally, although the metal/shell-weight index appears to be kept unchanged by seasonal factors other than metal bioavailability, the present results indicate the existence of seasonal trends in metal/

Fig. 5. Mytilus galloprovincialis. Seasonal variations in $\mathrm{Fe}, \mathrm{Zn}$, $\mathrm{Cu}, \mathrm{Ni}, \mathrm{Cd}, \mathrm{Cr}$ and $\mathrm{Pb}$ metal/shell-weight indices ( $\mu \mathrm{g}$ metal $\mathrm{g}^{-1}$ dry shell weight) recorded at 2 sampling sites, Arrigunaga ( - - - .), within the estuary, and Plentzia (--.--.), unpolluted and out of the estuary. Abbreviations as in Fig. 2 
shell-weight indices. Thus, these fluctuations might be attributed to different metal inputs at different times of the year. Alternatively, for the same environmental levels of a given metal, the ratio bioavailable/nonbioavailable metal might change as environmental factors change throughout the year (Luoma et al. 1985, Fischer 1986). Seasonal changes in sediment toxicity have also been described in absence of changes in the concentrations of chemical pollutants in the sediments (Borgmann \& Norwood 1993). Both increased metal bioavailability and concomitantly increased environmental toxicity might then be associated with seasonal changes in environmental factors.

In conclusion, metal/shell-weight indices provide a reliable tool to assess metal bioavailability in coastal waters to sentinel molluscs. It offers a low noise-to-signal ratio and a high sensitivity, and is easily calculated. Additionally, by simply using the weight calculated for biometric estimations in previous 'Mussel Watch' monitoring programmes, or by weighing stored shells, most of the previous records on metal bioavailability, based on the conventional use of metal concentrations, can be transformed into metal/shell-weight indices for comparisons.

Acknowledgements. We thank Mr I. Quincoces for the very skilful technical assistance. We also thank the staff and students of our lab for their help in sampling work and the always welcome comments made by Mrs M. Etxeberria and Dr M. P. Cajaraville. This work was funded by a research project of the CICYT (NAT90-0280) and by a research fellowship to M.S. by the Ministry of Education.

\section{LITERATURE CITED}

Abdullah AM, Ireland MP (1986) Seasonal studies on cadmium concentration and toxicity, oxygen consumption, digestive gland glycogen, and lipid in dog whelks collected at Aberystwyth, Wales. Mar Pollut Bull 17:562-566

Amiard JC, Amiard-Triquet C, Berthet B, Metayer C (1986) Contribution to the ecotoxicological study of cadmium, lead, copper and zinc in the mussel Mytilus edulis. I. Field study. Mar Biol 90:425-431

Azkona A, Jenkins SH, Roberts HMG (1984) Sources of pollution of the river Nervion, Spain - a case study. Wat Sci Technol 16:95-125

Borchardt T, Burchert S, Karbe L, Zeitner R (1989) Enhanced heavy metal concentrations in Mytilus edulis from the central North Sea. Scientia mar 53:725-728

Bordin G, McCourt J, Rodriguez A (1992) Trace metals in the marine bivalve Macoma balthica in the Westerschelde Estuary (The Netherlands). Part. 1. Analysis of total copper, cadmium, zinc and iron concentrations - locational and seasonal variations. Sci Total Environ 127:255-280

Borgmann U, Norwood WP (1993) Spatial and temporal variability in toxicity of Hamilton Harbour sediments: evaluation of the Hyalella azteca 4 -week chronic toxicity test. J Great Lakes Res 19:72-82

Boyden CR (1974) Trace element content and body size in molluscs. Nature 251:311-314
Boyden CR, Phillips DJH (1981) Seasonal variations and inherent variability of trace elements in oysters and their implication for indicator studies. Mar Ecol Prog Ser 5:29-40

Bryan GW (1976) Some aspects on heavy metal tolerance in aquatic organisms. In: Lockwood APM (ed) Effects of pollutants on aquatic organisms. Cambridge Univ Press, Cambridge, p 193

Cajaraville MP, Marigómez JA, Angulo E (1992) Comparative effects of the WAF of three oils on mussels. 1. - Survival, growth and gonad development. Comp Biochem Physiol 102:103-112

Chu KH, Cheung WM, Lau SK (1990) Trace metals in bivalves and sediments from the Tolo harbor, Hong Kong. Environ int 16:31-36

Cossa D, Bourget E, Piuze J (1979) Sexual maturation as a source of variation in the relationships between cadmium concentration and body weight of Mytilus edulis L. Mar Pollut Bull 10:174-176

Fischer $H$ (1983) Shell weight as an independent variable in relation to cadmium content of molluscs. Mar Ecol Prog Ser $12: 59-75$

Fischer H (1984) Cadmium body burden/shell weight of mussels: a precise index for environmental monitoring. Comm Meet int Coun Explor Sea CM-ICES/E 41:1-19

Fischer $H$ (1986) Influence of temperature, salinity and oxygen on the cadmium balance of mussels Mytilus edulis. Mar Ecol Prog Ser 32:265-278

Fischer H (1988) Mytilus edulis as a quantitative indicator of dissolved Cd. Final study and synthesis. Mar Ecol Prog Ser 48:163-174

Fischer H (1989) Cadmium in seawater recorded by mussels: regional decline established. Mar Ecol Prog Ser 55: $159-169$

Hawkins AJS, Bayne BL (1985) Seasonal variation in the relative utilization of carbon and nitrogen by the mussel Mytilus edulis: budgets, conversion efficiencies and maintenance requirements. Mar Ecol Prog Ser 25:181-188

Ikuta K (1988) Seasonal variations of some heavy metal concentrations in a venus clam Meretrix lusoria. Nippon Suissan Gakk 54:817-822

Kraak MHS, Scolten MCTh, Peeters WHM, de Kock WChr (1991) Biomonitoring of heavy metals in the western European rivers Rhine and Meuse using the freshwater mussel Dreissena polymorpha. Environ Pollut 74:101-114

Lobel PB, Wright DA (1982a) Relationship between body zinc concentration and allometric growth measurements in the mussel Mytilus edulis. Mar Biol 66:145-150

Lobel PB, Wright DA (1982b) Total body zinc concentration and allometric growth ratios in Mytilus edulis collected from different shore levels. Mar Biol 66:231-236

Lobel PB, Bajdik CD, Belkhode SP, Jackson SE, Longerich MP (1991) Improved protocol for collecting mussel watch specimens taking into account sex, size, condition, shellshape and chronological age. Arch environ Contam Toxicol 21:409-414

Luoma SN, Cain D, Johansson C (1985) Temporal fluctuations of silver, copper and zinc in the bivalve Macoma balthica at five stations in South San Francisco Bay. Hydrobiologia 129:109-120

Majori L, Nedoclan G, Modonutti B, Daris F (1978) Study of the seasonal variations of some trace metals in the tissues of Mytilus galloprovincialis taken in the Gulf of Trieste. Revue int Océanogr Méd 39:30-37

Marigómez I, Ireland M P (1990) A laboratory study of cadmium exposure in Littorina littorea in relation to environmental cadmium and exposure time. Sci Total Environ 90: $75-87$ 
Marigómez I, Ireland MP, Angulo E (1990) Correlation of cadmium shell-weight index with environmental stress indicators at the cellular and organismic levels in Littorina littorea. Mar Ecol Prog Ser 67:171-176

Marigómez I, Soto M. Angulo E (1992a) Seasonal variability in the quantitative structure of the digestive tubules of Littorina littorea. Aquat living Resour 5:299-305

Marigómez I, Soto M, Etxeberria M, Angulo E (1992b) Selection of mussels watch specimens based on metal/shell-wt indices and on organismic and cellular condition indices. 2nd European Conference on Ecotoxicology, Amsterdam (Abstract)

Martin M (1992) California mussel watch: monitoring metal and organic toxicants in marine waters. In: Miskiewicz AG (ed) Proc Bioacc Workshop. Water Board and Australian Marine Sciences Ass Inc, Sydney, p 15-37

Morchid A (1989) Biochemical composition of cultured mussels (Mytilus galloprovincialis Lmk.) from the gulf of Fos (NW Mediterranean Sea). Seasonal changes in lipid components and fatty acids. Haliotis 19: 357-371

Pentreath RJ (1973) The accumulation from water of ${ }^{65} \mathrm{Zn}$, ${ }^{54} \mathrm{Mn},{ }^{58} \mathrm{Co}$ and ${ }^{59} \mathrm{Fe}$ by the mussels Mytilus edulis. J mar biol Ass UK 53:127-143

Phillips DJH (1976) The common mussel Mytilus edulis as an indicator of pollution by zinc, cadmium, lead and copper. I. Effects of environmental variables on uptake of metals. Mar Biol 38:56-59

Phillips DJH (1980) Quantitative aquatic biological indicators. Applied Science, Barking

Rainbow PS (1993) The significance of trace metal concentrations in marine invertebrates. In: Dallinger $\mathrm{R}$, Rainbow PS

This article was submitted to the editor (eds) Ecotoxicology of metals in invertebrates. Lewis Publ, Boca Raton, p 3-23

Regoli F, Orlando E (1993) Mytilus galloprovincialis as a bioindicator of lead pollution: biological variables and cellular responses. Sci Total Environ (Suppl) 2:1283-1292

Ruiz de la Rosa JM, Saiz Salinas JI (1993) Bioavailability of heavy metals in two estuaries of the Basque Country. Actes III Coll int Oceanogr Golfe Gasc 1993:111-116

Savari A, Lockwood APM. Sheader M (1991) Effects of season and size (age) on heavy metal concentrations of the common cockle (Cerastoderma edule (L.)) from Southampton Water. J mollusc Stud 57:45-57

Swindlehurst RJ, Johnston PA (1991) Grave contaminación ambiental por metales pesados y HAPs en Bilbao, España. Technical Report Greenpeace, Queen Mary and Westfield College, University of London

Strömgren $T$, Nielsen MV (1991) Spawning frequency, growth and mortality of Mytilus edulis larvae, exposed to copper and diesel oil. Aquat Toxicol 21:171-180

Talbot V (1985) Heavy metal concentration in the oyster Saccostrea cucullata and Saccostrea sp (probably S. commercialis) from the Dampier archipielago, Western Australia. Aus J mar Freshwat Res 36:169-175

Thomson J D (1982) Metal concentration changes in growing Pacific oysters, Crassostrea gigas cultivated in Tasmania, Australia. Mar Biol 67:135-142

Widdows J, Donkin P (1989) The application of combined tissue residue chemistry and physiological measurements of mussels (Mytilus edulis) for the assessment of environmental pollution. Hydrobiologia 188/189; $455-461$

Manuscript first recelved: August 9, 1994

Revised version accepted: March 23, 1995 